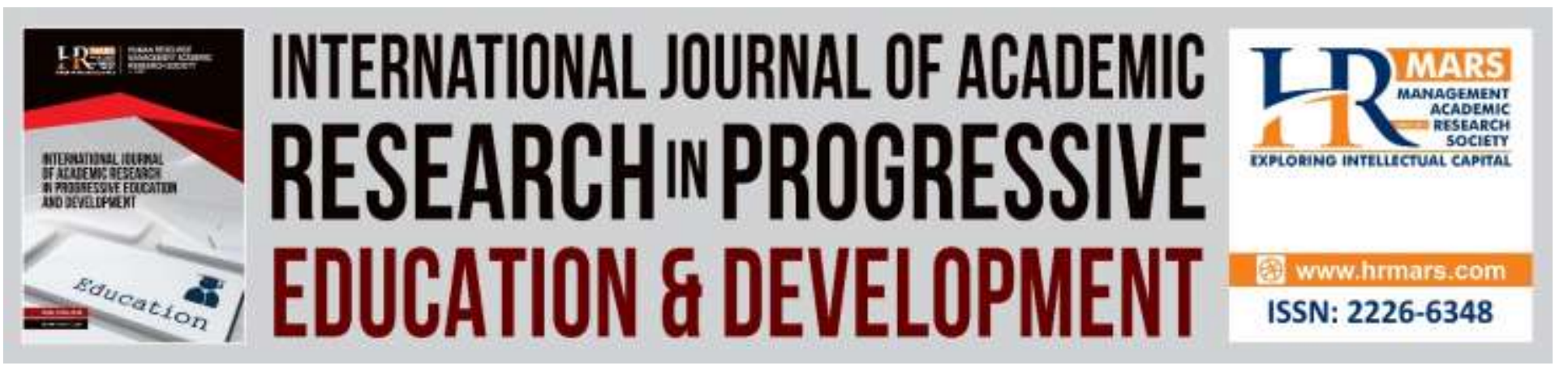

\title{
Cultivating Blended Learning in Teaching and Learning: Teachers' Intrinsic and Extrinsic Readiness in Malaysia
}

\author{
Noraini Mohamed Noh, Norazilawati Abdullah, Wong Kung Teck \& Mahizer \\ Hamzah
}

To Link this Article: http://dx.doi.org/10.6007/IJARPED/v8-i2/5778

DOI: $10.6007 /$ IJARPED/v8-i2/5778

Received: 25 March 2019, Revised: 23 April 2019, Accepted: 18 May 2019

Published Online: 24 May 2019

In-Text Citation: (Noh, Abdullah, Teck, \& Hamzah, 2019)

To Cite this Article: Noh, N. M., Abdullah, N., Teck, W. K., \& Hamzah, M. (2019). Cultivating Blended Learning in Teaching and Learning: Teachers' Intrinsic and Extrinsic Readiness in Malaysia. International Journal of Academic Research in Business and Social Sciences, 8(2), 257-265.

Copyright: (C) 2019 The Author(s)

Published by Human Resource Management Academic Research Society (www.hrmars.com)

This article is published under the Creative Commons Attribution (CC BY 4.0) license. Anyone may reproduce, distribute, translate and create derivative works of this article (for both commercial and non-commercial purposes), subject to full attribution to the original publication and authors. The full terms of this license may be seen

at: http://creativecommons.org/licences/by/4.0/legalcode

Vol. 8(2) 2019, Pg. 257 - 265

http://hrmars.com/index.php/pages/detail/IJARPED

JOURNAL HOMEPAGE

Full Terms \& Conditions of access and use can be found at http://hrmars.com/index.php/pages/detail/publication-ethics 


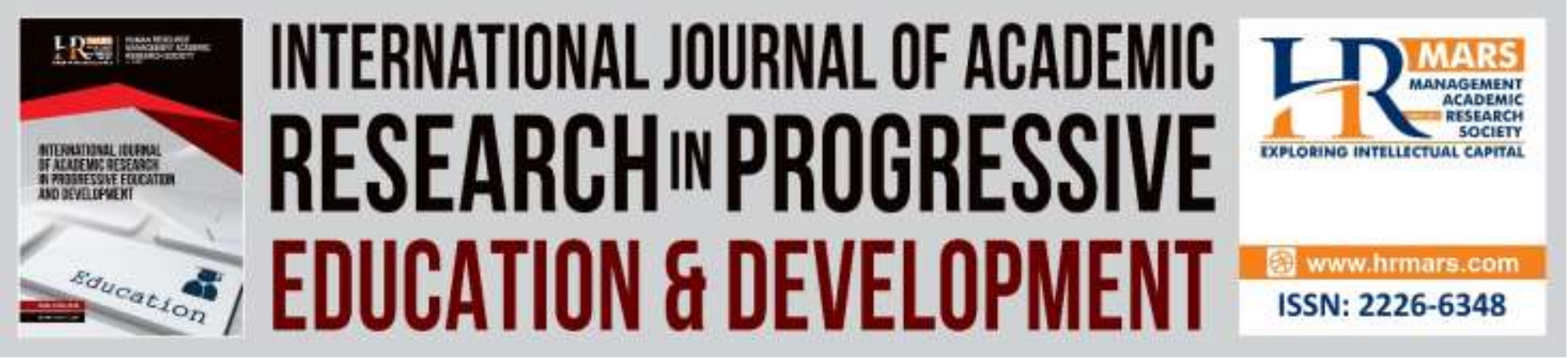

\title{
Cultivating Blended Learning in Teaching and Learning: Teachers' Intrinsic and Extrinsic Readiness in Malaysia
}

\author{
Noraini Mohamed Noh, Norazilawati Abdullah, Wong Kung Teck \& \\ Mahizer Hamzah \\ Faculty of Human Development, Sultan Idris Education University 35900 Tanjong Malim, Perak, \\ Malaysia \\ Email: noraini.mn@fpm.upsi.edu.my
}

\begin{abstract}
This study aims to ascertain teachers' intrinsic and extrinsic factors and their relationship towards the blended learning approach in teaching and facilitating. The study was conducted on 200 primary school teachers who were teaching in a few schools in Selangor and Perak and the sample was selected randomly. The questionnaire contained 11 constructs and self-reporting items were chosen to obtain the data. The findings indicated that there was a moderate positive relationship for intrinsic teacher factors such as individual innovation, information technology specific innovation, computer self-efficacy, ICT knowledge and skills with blended learning practice. There was also a moderate positive relationship for extrinsic teacher factors such as administrators' support, role of change agents, school and training facilities with blended learning approach in teachers' teaching and learning. As such, to ensure the success of the implementation of the blended learning approach as well as to increase its practice, the administrators should work to increase the teachers' academic awareness via promotions, preparing physical and technical facilities, providing support and practice continuously, creating an online learning culture and giving initiative and acknowledgement for teachers who are intent on making blended learning a success.
\end{abstract}

Keywords: Blended Learning, Personal Innovativeness, Computer Self-Efficacy, Change Agent, Technology Acceptance, Teacher Readiness

\section{Introduction}

In the era of 21st century education, the rapid development of education has opened up opportunities for developing countries to develop and produce citizens who are highly skilled and educated. To fulfill the challenge in the context of Malaysian education, teachers are required to make the education system reformation a success in line with the suggestion in Pelan Pembangunan Pendidikan Malaysia (PPPM) 2016-2020, which is now in its second wave. Some of 
the efforts include looking for ICT solutions to help the teachers in their teaching practice so that they could fully utilize the system developed by the KPM. Today, there is even the concept of a virtual university, a university without traditional classrooms. For example, the implementation of teaching using the Frog VLE virtual learning environment provides an opportunity for teachers to diversify the approaches in teaching instruction so that students can be exposed to a set of relevant skills to handle future challenges in line with the 4.0 Industrial Revolution. Using this new innovation, a learning environment can be created from a blend of face-to-face and non-face-toface learning approaches. A learning environment created from this blend has been accepted and recognized as the Blended Learning approach. (Wayne, 2012) as it is in line with the features and concept in the blended learning (Huang, Ma, \& Zhang, 2008).

Many studies have been conducted to identify the advantages of Blended Learning and its role in producing an effective learning process as well as its positive effect towards students' intellectual skills development, such Bottge et al., (2014), Briggs (2014), Chang et al., (2014), Isiguzel (2014) Lee and Hung (2015). Blended Learning is able to increase the flexibility features in students' learning process, whereby learning can occur anytime and in any place which has ICT facilities (Martin et al., 2015) providing opportunities to students to increase their learning knowledge and skills (Bachman \& Scherer, 2015; Wayne, 2012) and to increase the students' motivation level (Nurain et al, 2015). However, for the purpose of designing the best Blended Learning approach, the instructional events should be structured through systematic planning and based on accurate instructional basics. As such, teachers still require comprehensive support from the administrator in implementing the integrated learning (Vatanartiran \& Karadeniz, 2015). Additionally, Siew-Eng and Muuk (2015) stated that through the Blended Learning approach, teachers' instructional skills can be improved, while at the same time diversifying the teachers' teaching styles in making the learning process a success. To prove the teachers' requirement in implementing Blended Learning at schools, Korkmaz and Karakus (2009), Almasaeid (2014), VanDerLinden (2014) and Azli (2016) all agree that Blended Learning is able to produce meaningful learning through: (1) its ability to fulfill the needs of acquiring 21 st century learning, (2) continuous learning, (3) cost effectiveness. While Wu et al, (2016) stated that the learning process which utilized the Blended Learning approach could produce better learning achievement compared to face-to-face (traditional) and full online learning.

In order to make teaching and learning using Blended Learning a success, the teachers would need a systematic process starting from the integration of learning with Blended Learning, designing teaching by taking into account the elements of Blended Learning, implementing suitable teaching with the current learning design, always assessing the effectiveness of each phase and design of Blended Learning and always making improvements by re-planning the learning approach process based on the identified weaknesses. It is clear that in the effort to encourage teachers to utilise blended learning based on Frog VLE as a learning platform, the learning activity greatly depends on the pedagogy, learning experience and the teacher-implemented learning resource. Although the teacher generally has a positive perception and is very confident on the ability of ICT to increase students' learning success (Nazuar, 2014, Noraini 2016b,), the aspect of practice in teaching and learning had a very low usage (Hamzah et al., 2010; Rahayu, 2011; Nazuar, 2014; Zah, Hajar, Azimi, \& Hayati, 2009). This situation showed that there were signs or symptoms which hindered the teacher to implement the integration of ICT in the learning process. 
INTERNATIONAL JOURNAL OF ACADEMIC RESEARCH IN PROGRESSIVE EDUCATION AND DEVELOPMENT

Vol. 8, No. 2, 2019, E-ISSN: 2226-6348 @ 2019 HRMARS

In realizing the government's wish to develop an education system in line with the current technological advancement, teachers need to be mentally and physically ready to upgrade the innovation as best as they can as a preparation for the alpha generation kids. This is where the challenge begins in the education world to prepare the children for a competitive future. The teaching and learning approaches used should not be at the same stagnant level. The usage of technology should be in line with the needs of the current generation. The alpha generation is very much advanced compared to the previous Generation $Y$ and $Z$. in terms of technological usage. Studies by Magdy (2016), that to investigate and measure undergraduate students' attitudes towards blended learning environments shows that student positive attitudes towards was (71.5\%) but student negative attitudes towards was (17.2\%), finally the study recommended to use blended learning environments among undergraduate students.

The former would become easily bored if the teaching method in schools is still utilizing the old approach. The current generation requires a fresh new perspective to produce creative ideas. While Kementerian Pelajaran Malaysia (KPM) has done a lot to encourage teachers to utilize technology in teaching, the results have not been impressive. Some teachers are not using the technology creatively and effectively due to their own attitude. The teachers' attitude towards technology acceptance is influenced by aspects such as the extent of their trust in the benefits of technology compared to the existing technology used, suitability with current practices, usability and functionality (McDonald et al., 2004), difficult for teachers to change their teaching and facilitating styles (Noraini, 2016), unwilling to take risks, unwilling to try innovation (Van Fleet \& Walker, 2003). This will hinder one to accept new technology openly (Hunt et al. 2004; Weston, 2005). Furthermore, some teachers still need full support from the administrator to implement the teaching and learning integration (Vatanartiran \& Karadeniz, 2015). The question remains whether teachers at schools have utilized blended learning approach in their teaching and learning at schools.

\section{Study Objectives}

1. To ascertain the teachers' readiness in terms of ICT skills, computer self-efficacy, individual innovation, information technology specific innovation, knowledge on blended learning, support from administrators, the role of change agents, facilities and training among teachers.

2. To find out the level of usage for the blended learning approach in teachers' facilitating and learning.

3. To identify the relationship between ICT skills, computer self-efficacy, individual innovation, information technology specific innovation, knowledge on blended learning, support from administrators, the role of change agents, facilities and training among teachers with the blended learning approach in teachers' facilitating and learning.

\section{Study Methodology}

The quantitative nature of the survey method was chosen due to its appropriateness for discussing some of the aspects such as phenomenon and relationship in the education variable. Additionally, the survey method was chosen as this study resembled a self-report which required teachers to assess their feelings, strengths and weaknesses in introspective (Jackson, 2006). The study sample 
comprised 200 teachers chosen using the simple random method from schools in Selangor and Perak. The questionnaire was utilized for acquiring data in this study. The researcher had used an instrument adapted from a few other instruments according to the constructs, such as computer self-efficacy adapted from Hu et al., (2003) and Gong et al., (2004), blended learning approach usage adapted from Azli (2016), while the one for ICT skills had been adapted from Noraini (2014).

\section{Findings}

The mean for teachers' individual innovation $(m=3.37)$, self- efficacy $(m=3.03)$, specific innovation $(m=3.33)$, ICT skills $(m=3.33)$, knowledge about blended learning $(m=3.01)$ were all at moderate levels. As for level of administrators' support $(m=3.43)$, technology facility $(m=3.54)$, training $(m=3.28)$ and the role of change agents $(m=3.30)$ were all at moderate level. The level of blended learning in teachers' teaching and learning was at moderate level $(m=3.01)$.

There was a moderate positive relationship between ICT skills $(r(200)=0.67, p=0.00$ $(p<0.01)$, computer self-efficacy $(r(200)=0.71, p=0.00(p<0.01)$, individual innovation $(r(200)=0.53$, $p=0.00(p<0.01)$, information technology specific innovation $(r(200)=0.59, p=0.00(p<0.01)$, blended learning knowledge $(r(200)=0.62, p=0.00(p<0.01)$, administrators' support $(r(150)=0.58$, $p=0.00(p<0.01)$, role of change agents $(r(200)=0.54, p=0.00(p<0.01)$, facility $(r(200)=0.48, p=$ $0.00(p<0.01)$ and training $(r(200)=0.59, p=0.00(p<0.01)$.

\section{Discussion}

The findings showed that the individual innovation level was high but the specific information technology level was moderate. This indicated that the teachers were not prepared to know how to implement teaching and learning using blended learning and were unprepared to implement it. From this we can ascertain that the teachers who were very open towards a new innovation in their lives might also be so open towards accepting more specific innovation such as the usage of blended learning in their teaching. While this study found that $78.8 \%$ of teachers had Internet access at home and $90.8 \%$ had personal computers, these aspects did not guarantee that the they would be excited to learn new technology and pedagogy towards creating a 21st century teaching environment which includes blended learning and its usage. This could be due to the teachers' lack of new knowledge about the variety of teaching methods from time to time and this caused them to be less innovative. As such, teachers' knowledge about blended learning is important to prepare them to utilize the approach effectively in their teaching and learning. The pedagogical knowledge can encourage teachers towards firstly, building awareness, whereby it can motivate them to learn more about blended teaching and later accept it. If the teachers do not have clear information about blended learning, they might have the perception that the approach would not be suitable to be applied in the classroom. Secondly, teachers should also have knowledge of how to implement blended learning in the best way in teaching and learning. This is in line with Rogers' (2003) suggestion that in order to increase acceptance towards an innovation, the individual should have knowledge of it or at least how to use that innovation. Thirdly, the teachers should have knowledge of principles and functions which would be the basis of how and why innovation in teaching pedagogy were invented. On the other hand, if the teacher is not clear about blended learning, this would cause the end of the usage of pedagogy innovation and its acceptance. 
The findings also showed a moderate level of teacher computer self-efficacy. This aspect also showed a significant direct relationship with blended learning in the teaching and learning process. This showed us that high computer self-efficacy could encourage the teachers to use blended learning in their teaching and learning process while teachers who had low computer selfefficacy would create obstacles in themselves to avoid using blended learning in their classroom. According to Bingimalas (2009), the lack of confidence of teachers to use ICT and the lack of openness towards innovation were some obstacles for teachers to apply ICT in their teaching. Teacher computer self-efficacy could be improved by giving them practice or training related to technology usage especially Frog VLE as a learning platform; it is a technology which helps blended learning to be implemented. As such, intrinsic factors such as individual innovative level, information technology specific innovation and high ICT skills are important as catalysts to implement blended learning in teaching and learning.

To ensure that blended learning could be cultivated, extrinsic aspects such as administrator support, role of change agents, school facilities and training have a good relationship with its practice in teaching and learning. Inspiration and support from administrators are important for the success of an innovation's implementation at school. Without continuous support from the administrator, the teachers would lose the drive to accept innovation and they would be likely to use conventional teaching. As such, the school administrators would need to act as leaders of change and supporters of teacher competency. Therefore, administrators should encourage more blended learning by organizing workshops, promotions or by giving incentives to teachers at school. The administrators' support or any other change agents at school can provide implications towards the teachers' acceptance of the innovation introduced at schools and whether they would use it or only use it if there are directives from the authorities or avoid using the innovation totally.

\section{Contribution of the Study}

This study made several notable contributions to the understanding of teachers' intrinsic and extrinsic factors towards blended learning practices. The findings may be of interest to administrators, policy makers, curricular designers and teachers. The contributions of this study can be conceptualized into theoretically and practically. An important contribution from the study was that it offers a significant starting point for an expansion of future theoretical analyses of blended learning among teachers in Malaysia. The findings provide insight and expand upon current conceptual and theoretical regards teachers' intrinsic and extrinsic in influencing the use of blended learning in teaching and learning. It is noted that although moderating effects were founded, it was not given due attention in past studies. Besides from the practical standpoint, the onus lies on the Ministry of Education, Malaysia and higher education institutions to conduct inservice or pre-serving professional program to improve the levels of teachers' intrinsic and extrinsic towards blended learning in their daily teaching classes.

\section{Acknowledgement}

The authors would like to express their utmost gratitude to the Research Management and Innovation Centre, UPSI for the allocation of University Special Research Grant (2017-0279-10701) 
INTERNATIONAL JOURNAL OF ACADEMIC RESEARCH IN PROGRESSIVE EDUCATION AND

DEVELOPMENT

Vol. 8, No. 2, 2019, E-ISSN: 2226-6348 @ 2019 HRMARS

\section{References}

Almasaeid, T. F. (2014). The effect of using blended learning strategy on achievement and 9th grade students. European Scientific Journal, 10(31), 133-145. From

http://eujournal.org/index.php/esj/article/viewFile/4573/4370

Bachman, C., \& Scherer, R. (2015). Promoting student autonomy and competence using a hybrid model for teaching physical activity. International Journal of Instruction, 8(1). From http://www.e-iji.net/dosyalar/iji_2015_1_1.pdf

Bingimalas, K. A. 2009. Barriers to successful integration of ICT in teaching and learning environments: A review of the literature. Eurasia Journal of Mathematics, Science \& technology Education 5(3): 235-245

Bottge, B. A., Ma, X., Gassaway, L., Toland, M. D., Butler, M., \& Cho, S.-J. (2014). Effects of blended instructional models on math performance. Exceptional Children, 80(4), 423-437. http://doi.org/10.1177/0014402914527240

Briggs, K. C. (2014). Blended learning vs face-to-face instruction: a quantitative evaluation of student achievement in algebra I. Northcentral University.

Chang, C. C., Shu, K. M., Liang, C., Tseng, J. S., \& Hsu, Y. S. (2014). Is blended e-learning as measured by an achievement test and self-assessment better than traditional classroom learning for vocational high school students? International Review of Research in Open and Distance Learning, 15(2), 213-231.

Gong, M., Xu, Y \& Yu, Y.H. 2004. An Enhanced technology acceptance model for web-based learning. Journal of Information Systems Education 15(4): 365-347

Hamzah, M. I., Embi, M. A., \& Ismail, A. (2010). ICT and diversity in learners' attitude on smart school initiative. Procedia - Social and Behavioral Sciences, 7(C), 728-737. http://doi.org/10.1016/j.sbspro.2010.10.099

Hamzah, M. I., Embi, M. A., \& Ismail, A. (2010). ICT and diversity in learners' attitude on smart school initiative. Procedia - Social and Behavioral Sciences, 7(C), 728-737. http://doi.org/10.1016/j.sbspro.2010.10.099

Hu, P. J., Clark, T. H. K. \& Ma, W. W. 2003. Examining technology acceptance by school teachers: a longitudinal study. Information \& Management 41(2): 227-241

Huang, R., Ma, D., \& Zhang, H. (2008). Towards a design theory of blended learning curriculum. In J. Fong, R. Kwan, \& F. L. Wang (Ed.), Hybrid Learning and Education (hal. 66-78). Berlin: Springer Berlin Heidelberg. http://doi.org/10.1007/978-3-540-85170-7

Hunt, L., Eagle, L. \& Kitchen, P.J. 2004. Balancing marketing education and information technology: matching needs or needing a better match. Journal of Marketing Education 26(1): 75-88

Isiguzel, B. (2014). The blended learning environment on the foreign language learning process: a balance for motivation and achievement. Turkish Online Journal of Distance EducationTOJDE, 15(3(10)), 108-122.

Jackson, S.L. 2006. Research Methods and Statistics: A Critical Thinking Approach. Edisi ke-2. Belmont, CA: Thomson Wadsworth

Korkmaz, O., \& Karakus, U. (2009). The impact of blended learning model on student attitudes towards geography course and their critical thinking dispositions and levels. The Turkish Online Journal of Distance Education, 8(4), 51-63. From dari

http://files.eric.ed.gov/fulltext/EJ859497.pdf 
INTERNATIONAL JOURNAL OF ACADEMIC RESEARCH IN PROGRESSIVE EDUCATION AND

DEVELOPMENT

Vol. 8, No. 2, 2019, E-ISSN: 2226-6348 @ 2019 HRMARS

Lee, L. T., \& Hung, J. C. (2015). Effects of blended e-learning: a case study in higher education tax learning setting. Human-centric Computing and Information Sciences, 5(1), 13. http://doi.org/10.1186/s13673-015-0024-3

Martin, J. S., Kreiger, J. E., \& Apicerno, A. L. (2015). Effectiveness of a hybrid classroom in the delivery of medical terminology course content relative to a traditional classroom format. Journal of the Scholarship of Teaching and Learning, 15(5), 72-81. http://doi.org/10.14434/josotl.v15i5.13994

Magdy, S. A. (2016), Measuring Attitudes toward Blended Learning Environment among Undergraduate Students in Palestine, International Journal of Academic Research in Progressive Education and Development 2016, Vol. 5, No. 4 ISSN: 2226-6348. http://dx.doi.org/10.6007/IJARPED/v5-i4/2454

McDonald, J, McPhail, J., Maguire, M. \& Millett, B. 2004. A conceptual model and evaluation process for educational technology learning resources: a legal case study. Educational Media International 41(4): 281-90.

Misman, J., Sharipp, M. T. M., Sharipp, M. T. M., \& Shaidin, S. (2019). Islamic Perspectives: Using New Media in Education. International Journal of Academic Research in Progressive Education and Development, 9(1), 12-21.

Azli, M. (2016). Blended learning: Pedagogy, learning styles, and assessment activities in the classroom. International Journal of Advanced and Applied Sciences, 3(11), 36-39.

Yeop, M. A. (2016). Blanded learning: A literature review on teacher acceptance factors through acceptance models. Journal of Research, Policy \& Practice of Teachers \& Teacher Education, 6(1), 67-85.

Nurain, R., Balakrishnan, M., \& Wan, A. J. W. Y. (2015). Attitude and motivation of Malaysian secondary school students â€TM learning of ESL in a blended learning environment. In eProceeding of the Global Conference on Technology in Language Learning 2015. http://doi.org/10.13140/RG.2.1.4966.6646

Rogers, E. M. (2003). Diffusion of Innovations. Edisi ke-5. New York: Free Press.

Seri Rahayu, H. (2011). Teachers' beliefs and use of ICTs in malaysian smart schools: a case study. In Changing Demands, Changing Directions. Proceedings ascilite Hobart 2011 (hal. 522525).http://www.ascilite.org.au/conferences/hobart11/downloads/papers/Hamidposter.pdf

Siew-Eng, L., \& Muuk, M. A. (2015). Blended learning in teaching secondary schools' English: a preparation for tertiary science education in Malaysia. Procedia - Social and Behavioral Sciences, 167(October), 293-300. http://doi.org/10.1016/j.sbspro.2014.12.677

Siti Nazuar, S. (2014). Barriers influencing teacher 's technology integration in their teaching practice. Australian Journal of Basic and Applied Sciences, 8(23), 352-357.

Van Fleet, C. \& Wallace, D. 2003. Virtual libraries: real threats. Reference \& User Services 42: 188191.

Vatanartiran, S., \& Karadeniz, S. (2015). A needs analysis for technology integration plan: challenges and needs of teachers. Contemporary Educational Technology, 6(3), 206-220.

Diambil Dari

http://web.a.ebscohost.com.ezpustaka.upsi.edu.my/ehost/pdfviewer/pdfviewer?sid=028 39cfb-7b1d-47cb-871a-361f9d93bc8f@sessionmgr4002\&vid=1\&hid=4204 
INTERNATIONAL JOURNAL OF ACADEMIC RESEARCH IN PROGRESSIVE EDUCATION AND DEVELOPMENT

Vol. 8, No. 2, 2019, E-ISSN: 2226-6348 @ 2019 HRMARS

Vatanartiran, S., \& Karadeniz, S. (2015). A needs analysis for technology integration plan: challenges and needs of teachers. Contemporary Educational Technology, 6(3), 206-220. Taken from http://web.a.ebscohost.com.ezpustaka.upsi.edu.my/ehost/pdfviewer/pdfviewer?sid=028 39cfb-7b1d-47cb-871a-361f9d93bc8f@sessionmgr4002\&vid=1\&hid=4204

Wan Zah, W. A., Hajar, M. N., Azimi, H., \& Hayati, A. (2009). The conditions and level of ICT integration in Malaysian Smart Schools. International Journal of Education and Development using ICT, 5(2), 21-31. Taken from

http://ijedict.dec.uwi.edu//viewarticle.php?id=618\&layout=html

Wayne, J. (2012). Effective learning - blended learning and virtual learning environment. Taken from

http://www.selfgrowth.com/articles/effective-learning-blended-learning-and-virtual-learningenvironment.

Weston, T. J. (2005). Why faculty did-or did not - integrate instructional software in their undergraduate classrooms. Innovative Higher Education 30(2): 99-115

Wu, Y., Wen, M., Chen, C., \& Hsu, I. (2016). An integrated BIM and cost estimating blended learning model - acceptance differences between experts and novice. Eurasia Journal of Mathematics, Science \& Technology Education, 12(5), 1347-1363.

http://doi.org/10.12973/eurasia.2016.1517a 